\title{
Determinants of pneumonia among 2-59 months old children at Debre Markos referral hospital, Northwest Ethiopia: a case-control study
}

\author{
Sefinew Getaneh', Girma Alem², Maru Meseret ${ }^{2}$, Yihun Miskir ${ }^{3^{*}}$ (D), Tilahun Tewabe ${ }^{3}$, Gebeyaw Molla $^{4}$ and
} Yihalem Abebe Belay ${ }^{2}$

\begin{abstract}
Background: Pneumonia is a significant public health problem globally. The early identification and management of the determinants of pneumonia demands clear evidence. But, there is a limited data on this issue in the current study area. Thus, this study aimed to identify the determinants of pneumonia among 2-59 months old children at Debre Markos Referral Hospital, Northwest Ethiopia.

Methods: A Hospital based unmatched case-control study was conducted among 334 (167 Cases and 167 Controls) children at Debre Markos Referral Hospital from February 1 to March 30, 2018. Consecutive sampling technique was employed and data were collected with a pre-tested interviewer administered questionnaire. Data were entered into Epi-Data version 4.2, and analyzed using SPSS version 25 software. Bi-variable and multi-variable logistic regression analyses were fitted. Variables having $p$-value $<0.05$ were considered as statistically significant.

Results: A total of 328(164 cases and 164 controls) 2-59 months old children were included in this study. Not opening windows daily [AOR:6.15(2.55,14.83)], household near to the street [AOR:4.23(1.56,11.44)], child care by the house workers and relatives [AOR:2.97 (1.11,7.93)], using only water for hand washing before child feeding [AOR:3.81 $(1.51,9.66)]$, mixed feeding practice from birth to six months [AOR: $7.62(2.97,19.55)]$, having upper respiratory tract infection in the last 2 weeks for the child [AOR: $5.33(2.16,13.19)]$ and children with history of co- residence with URTI family [AOR: $6.17(2.36,16.15)]$ were found to be determinants of pneumonia.
\end{abstract}

Conclusions: The main contributing factors for pneumonia in this study are preventable with no or minimal cost. Therefore, we recommend appropriate and adequate health education regarding pneumonia prevention and control.

Keywords: Determinants, Pneumonia, Under five children, Referral hospital, Debre Markos

\section{Background}

Pneumonia remains the leading cause of death in children under five years old worldwide. In 2016, pneumonia accounts for 15.6 and $17 \%$ of all deaths in this age group globally and in Sub-Saharan Africa respectively [1]. Most of these deaths occurred in developing countries where access to care is limited and interventions that have improved care in developed countries are scarce [2]. In

\footnotetext{
* Correspondence: yihun100@gmail.com

${ }^{3}$ Collegeof Medicine and Health Science, Bahir Dar University, Bahir Dar, Ethiopia

Full list of author information is available at the end of the article
}

Ethiopia, pneumonia contributes for $16.4 \%$ of all deaths of children under five years of age more than diarrhea, malaria, AIDS and measles combined [1]. The WHO/ UNICEF developed the integrated Global Action Plan for Pneumonia and Diarrhea (GAPPD) in 2013 to end preventable child deaths from Pneumonia and Diarrhea by 2025 [3]. In addition, the Federal Ministry of Health of Ethiopia (EFMOH) has incorporated pneumococcal conjugate vaccine in its expanded program on immunization in 2011 to prevent against the severe forms of pneumococcal disease in childhood [4]. Despite the global and

(c) The Author(s). 2019 Open Access This article is distributed under the terms of the Creative Commons Attribution 4.0 International License (http://creativecommons.org/licenses/by/4.0/), which permits unrestricted use, distribution, and reproduction in any medium, provided you give appropriate credit to the original author(s) and the source, provide a link to the Creative Commons license, and indicate if changes were made. The Creative Commons Public Domain Dedication waiver (http://creativecommons.org/publicdomain/zero/1.0/) applies to the data made available in this article, unless otherwise stated. 
government efforts, pneumonia in Ethiopia remains a considerable problem.

Beyond death, pneumonia in children could result in a substantial economic burden in the affected society. This is mainly related to the costs incurred during diagnosis, outpatient and inpatient treatment of cases at health facilities [5-9]. In Ethiopia, pneumonia leads affected households to be impoverished due to medical payments $[10,11]$.

Previous studies indicated that some of the most common risk factors for pneumonia include lack of exclusive breastfeeding, indoor air pollution, parental cigarette smoking, malnutrition, common co- morbid conditions, living in crowded house, keeping domestic animals inside the main house, using charcoal for cooking, advanced maternal age, previous upper respiratory tract infection, more than four family members, lack of zinc supplementation, absence of separate kitchen, absence of window in the kitchen, age of child, father's education, child cared by housekeeper and their relatives, history of diarrhea in child, house near to the street and household history of acute lower respiratory infection [12-20].

The contributing factors need be studied so as to better inform and educate the policy makers, programmers, implementers and the general population about the problem. There is limited evidence regarding the determinants of pneumonia in the current study area. Therefore, this study aimed to identify the determinants of pneumonia among 2-59 months old children at Debre Markos referral Hospital, Northwest Ethiopia.

\section{Methods}

\section{Study design, area and period}

A Hospital based unmatched case-control study design was employed at Debre Markos Referral Hospital, Amhara National Regional State, Northwest Ethiopia. The hospital offers a full range of health care services including child care. It is expected to serve a population of 2,153,937.The hospital has 193 beds used for inpatient services [21]. The study was conducted from February 1 to March 30, 2018.

\section{Population and eligibility criteria}

The source population was all 2-59 months old outpatient department (OPD) visitors in Debre Markos Referral Hospital. A case was defined as a child of age 2-59 months old who has attended in the hospital with a diagnosis of pneumonia within the study period. Diagnosis of pneumonia was determined by the assigned physician using the Federal Democratic Republic of Ethiopia Ministry of Health Integrated Management of Newborn and Childhood Illness (IMNCI) guideline [22] adopted from WHO. A control was defined as a child 2-59 months old who has attended in the Hospital with a diagnosis of non-pneumonia case in the study period. All 2-59 months old children who have attended the OPD of the hospital were included in the study. However, mothers or caregivers of children who were having hearing impairments or unable to talk were excluded from the study.

\section{Sample size determination and sampling procedure}

A sample size of 334 (167 cases and167 controls) was determined using Kelsey et al. formula [23] using the Epi-Info Version 3.5.1 software.

\section{Assumptions}

Assuming two sided confidence level $(\mathrm{CI})=95 \%$, Power $=80 \%$, ratio of controls to cases $=1: 1$ and taking history of parental smoking as a main predictor of Pneumonia with the percent of controls exposed 19.57\% and Odds Ratio 2.1 from a case control study in Southwest Ethiopia [16] and an estimated non-response rate of $10 \%$.

Both cases and their controls were selected by consecutive sampling technique from the under-five OPD visitors (aged 2-59 months old) until the required sample was reached. For every case of pneumonia, one control before or after the case was taken. Finally, interviewing of the mothers/care givers was carried out for both controls and cases.

\section{Data collection process and instrument}

Data were collected using a pretested-interviewer administered structured questionnaire. The questionnaire was prepared first in English and translated in to Amharic, then back to English to check for its consistency. The Amharic version of the questionnaire was used to collect the data. Primary data were collected through face to face interview of the mother/ care taker. Information regarding patient's diagnosis based on assigned physician, patient's weight/height, weight/age, patient's malnutrition status (malnourished or not), HIV tested or not, and patient's sero status (reactive or non-reactive) were collected from patient's medical records (patient's charts and registers). Two Nurses (first degree holder) at the hospital collected the data, and one General Practitioner supervised the whole data collection process. The data collectors and supervisor were trained for two days on the study objective and data collection process. The questionnaire was pretested on $5 \%$ of the sample size at Finoteselam Hospital, and amendments on the questionnaire were made accordingly. Intensive supervision was done by the supervisor and principal investigator throughout the data collection period. 


\section{Study variables}

The dependent variable in this study was Pneumonia. The independent variables were: Socio demographic factors (age of child and mother, sex of child, occupation of mother and father, educational status of mother and father, family size, marital status, age of the mother, residence and ethnicity); Home based and behavioral factors (presence of separated kitchen or not, household near to street, ventilation status of the house, number of windows and opening status, presence of cigarette smoker in the house); Nutritional factors, co- morbidities and care practice (breast feeding status of the child, vitamin A supplementation status, vaccination status of the child appropriate for age, HIV status of the child, history of diarrhea, malnutrition, URTI and co residence with URTI family member).

\section{Data processing and analysis}

The data were checked for completeness and consistencies. Data were also cleaned, coded and entered into Epi-Data software version 4.2, then exported to SPSS version 25 statistical package for analysis. The crude odds ratios with $95 \%$ confidence interval were estimated in the unadjusted logistic regression analysis to assess the association between each independent variable and the outcome variable. Variables with $p$-value $<0.25$ in the unadjusted logistic regression analysis were considered in the adjusted logistic regression analysis. The Hosmer-Lemeshow goodnessof-fit with enter procedure was used to test for model fitness. Adjusted odds ratios with 95\% confidence interval were estimated to assess the strength of the association, and variables with $p$-value $<0.05$ were considered significant factors.

\section{Ethical considerations}

Ethical clearance was obtained from Ethical Review Committee (ERC) of Debre Markos University, College of Health Sciences. Permission to conduct the study was also obtained from Debre Markos Referral Hospital administrators before data collection. Written consent was obtained from mothers after they were informed about the study objectives, expected outcomes, benefits and the risks associated with it. Confidentiality and privacy of every respondent's information were ensured.

\section{Results}

Socio-demographic characteristics of the study participants Out of 334 (167 cases and 167 controls) children who approached for interview, a total of 328 (164 cases and 164 controls) were included resulting in a response rate of $98.2 \%$. The mean age of the participants was 25.5 months with a range of 2 to 59 months old. The mean age of cases and controls were 19.7 and 30.8 months respectively. More than $80 \%$ of mothers both in cases and controls were above 24 years old. About 94 (57.3\%) of the cases and 109 $(66.5 \%)$ of the controls were residents in the urban areas (Table 1).

Table 1 Socio-demographic characteristics of participants in Debre Markos Referral Hospital, Northwest Ethiopia, 2018 ( $n=164$ cases $\& 164$ controls)

\begin{tabular}{|c|c|c|c|}
\hline \multirow[t]{2}{*}{ Variable } & \multirow[t]{2}{*}{ Category } & \multirow{2}{*}{$\begin{array}{l}\text { Case } \\
\text { N (\%) }\end{array}$} & \multirow{2}{*}{$\begin{array}{l}\text { Control } \\
\mathrm{N}(\%)\end{array}$} \\
\hline & & & \\
\hline \multirow[t]{2}{*}{ Sex of child } & Male & $98(59.8)$ & $89(54.3)$ \\
\hline & Female & $66(40.2)$ & $75(45.7)$ \\
\hline \multirow[t]{3}{*}{ Age of child (months) } & $2-11$ & $63(38.4)$ & $27(16.5)$ \\
\hline & $>11$ to $\leq 23$ & $44(26.8)$ & $31(18.9)$ \\
\hline & $>23$ to59 & $57(34.8)$ & $106(64.6)$ \\
\hline \multirow[t]{3}{*}{ Age of mother (years) } & $\leq 24$ & $27(16.5)$ & $24(14.6)$ \\
\hline & $>24$ to34 & $94(57.3)$ & $104(63.4)$ \\
\hline & $\geq 35$ & $43(26.2)$ & $36(22.0)$ \\
\hline \multirow[t]{3}{*}{ Marital status of parents } & Married & $138(84.1)$ & $155(94.5)$ \\
\hline & Divorced & $7(4.3)$ & $4(2.4)$ \\
\hline & Separated & 19 (11.6) & $5(3.0)$ \\
\hline \multirow{5}{*}{$\begin{array}{l}\text { Mother's educational } \\
\text { level }\end{array}$} & Not read and write & $72(43.9 \%)$ & 55 (33.5\%) \\
\hline & Primary education & $36(21.9 \%)$ & $41(25 \%)$ \\
\hline & $\begin{array}{l}\text { Secondary } \\
\text { education }\end{array}$ & $29(17.7 \%)$ & $18(10.9 \%)$ \\
\hline & Diploma & $21(12.5 \%)$ & $33(20.1 \%)$ \\
\hline & Degree and above & $6(3.6 \%)$ & 17 (10.4\%) \\
\hline \multirow[t]{5}{*}{ Father's educational level } & Not read and write & $59(36.0)$ & $45(27.4)$ \\
\hline & Primary education & $32(19.5)$ & $37(22.6)$ \\
\hline & $\begin{array}{l}\text { Secondary } \\
\text { education }\end{array}$ & $30(18.3)$ & $15(9.1)$ \\
\hline & Diploma & $18(11.0)$ & 19 (11.6) \\
\hline & Degree and above & $25(15.2)$ & $48(29.3)$ \\
\hline \multirow[t]{5}{*}{ Mother's occupation } & Farmer & $74(45.1)$ & $50(30.5)$ \\
\hline & house wife & $42(25.1)$ & $41(25.0)$ \\
\hline & civil servant & $26(15.9)$ & $42(25.6)$ \\
\hline & Merchant & $21(12.8)$ & $30(18.3)$ \\
\hline & Others & $1(0.6)$ & $1(0.6)$ \\
\hline \multirow[t]{4}{*}{ Father's occupation } & Farmer & $74(45.1)$ & $54(32.9)$ \\
\hline & Daily laborer & $13(7.9)$ & $9(5.5)$ \\
\hline & Civil servant & $46(28.0)$ & $66(40.2)$ \\
\hline & Merchant & $31(18.9)$ & $35(21,3)$ \\
\hline \multirow[t]{2}{*}{ Family member } & $\leq 4$ & $72(43.9)$ & $96(58.5)$ \\
\hline & $\geq 5$ & $92(56.1)$ & $68(41.5)$ \\
\hline \multirow[t]{2}{*}{ Residence } & Urban & $94(57.3)$ & $109(66.5)$ \\
\hline & Rural & 70 (42.7) & 55 (33.5) \\
\hline
\end{tabular}


Home based and behavioral factors related to pneumonia The houses for most of the cases (95.7\%) and the controls (97.0\%) had windows. About 35 (22.3\%) of cases and $141(88.7 \%)$ of controls had windows opened daily. Fifty two (42.1\%) of cases and sixteen (9.8\%) of controls had a kitchen attached to the living room. About $82(50.0 \%)$ of cases and $31(18.9 \%)$ of controls had only water for hand washing. Only $6(3.7 \%)$ of cases and $1(0.6 \%)$ of controls had cigarette smoking family member (Table 2).

\section{Co-morbidity related factors to pneumonia}

About 152(92.7\%) of cases tested for HIV and 3 (2\%) of them were sero-positive while from $73(44.5 \%)$ controls tested for HIV, 2(2.7\%) of them were sero-positive. Ten (6.1\%) of cases and $11(6.7 \%)$ of controls had malnutrition. About 123(37.5\%) of study participants, 107(65.2\%) cases and 16(9.8\%) controls had history of URTI for the last two weeks duration prior to the data collection period (Table 3).

\section{Nutritional related factors associated to pneumonia}

As shown in Table 4, about $66(40.2 \%)$ of cases and $148(90.2 \%)$ of controls were breastfed exclusively. About $137(83.5 \%)$ of cases and $151(92.1 \%)$ of controls were vaccinated.

\section{Bi-variable and multi-variable analysis result}

In the unadjusted analysis, a total of 12 variables were found to full fill the assumption of logistic regression at $p$-value of less than 0.25 and nominated for further analysis in the adjusted analysis. By using backward logistic regression method, 7 variables (windows daily opening status, household near to street, child care giver most of the time, hand washing material used before child feeding, birth to 6 months breast feeding practice, URTI in the last 2 weeks for the child and a child with history of co- residency with family member who had URTI) had showed significant association with pneumonia at $p$-value less than 0.05 .

The odds of developing pneumonia among children with no windows daily opening was 6.15 times more as compared to those children with windows daily opening [AOR:6.15 (2.55, 14.83)].

The probability of having pneumonia in children with a house near to the street was 4.23 times more as compared to those children with a house not near to the street [AOR:4.23 (1.56,11.44)].

Those children who got child care mostly from the house workers and relatives were 2.97 times more likely to develop pneumonia than those children who mostly got child care from their parents [AOR:2.97 (1.11,7.93)].

The odds of developing pneumonia among children with hand washing before feeding using water only was
3.80 more as compared to those children with hand washing using both water and soap [AOR:3.81 $(1.51,9.66)]$.

Those children who had mixed feeding were 7.62 more likely to develop pneumonia than those children with exclusive breast feeding from birth to six months [AOR: 7.62(2.97, 19.55)].

The likelihood of developing pneumonia in children who co-reside with a person with URTI was 6.17 times more as compared to their counterparts [6.17 $(2.36,16.15)]$.

Those children who had URTI in the last 2 weeks prior to the study period were 5.33 times more likely to have pneumonia than their counterparts [AOR:5.33 $(2.16,13.19)$ ] (Table 5).

\section{Discussion}

The main aim of this study was to investigate the determinants of pneumonia among 2-59 months old children at Debre Markos referral Hospital in Northwest Ethiopia.

In the current study, respondents who did not open their house windows daily were at higher risk of developing pneumonia than their counter parts. It is consistent with other studies which reported that poor indoor ventilation was the risk factor associated with pneumonia, and ventilation is poor in a house without window or unopened windows daily, house attached with kitchen or used for kitchen and living [12, 18, 24]. This could be due to the fact that dust particles stay to the house resulting indoor air pollution and may cause frequent respiratory problems which can progress to pneumonia especially in children as their immunity is under developed. Healthy homes require sufficient light, especially natural light in the form of ultraviolet light which can kill germs, bacteria, viruses, and fungi that can cause infection, allergies, asthma or other diseases [25].

In relation to child care giver's relationship with the child, children who got care by the house worker and relatives were at higher odds of developing pneumonia as compared to children who cared by their parents. This result is in line with a study conducted in Oromia Zone of Amhara region [14] where the study showed children cared by house keeper and their relatives were 2.79 times more likely to develop pneumonia as compared to children cared by their parents. This might be due to the fact that house workers and relatives may not be responsible for child caring as their parents such as keeping child's self-hygiene, feeding the child on time and other child care activities.

In the present study, those children from a house near to the street were at increased odds of developing pneumonia than those who were not lived near the street. This result is consistent with a study conducted in China which found that living near traffic-related 
Table 2 House characterstices of participantsin Debre Markos Referral Hospital, Northwest Ethiopia, 2018 ( $n=164$ cases and 164 controls)

\begin{tabular}{|c|c|c|c|c|}
\hline \multirow[t]{2}{*}{ Variables } & \multirow{2}{*}{\multicolumn{2}{|c|}{ Category }} & Case & Control \\
\hline & & & N (\%) & N (\%) \\
\hline \multirow[t]{2}{*}{ Does your house have window? } & \multicolumn{2}{|l|}{ Yes } & $157(95.7)$ & $159(97.0)$ \\
\hline & \multicolumn{2}{|l|}{ No } & $7(4.3)$ & $5(3.0)$ \\
\hline \multirow[t]{2}{*}{ Number of windows ( $n=326 ; 157$ for cases and 159 for controls) } & \multicolumn{2}{|c|}{ Two and less } & $122(77.7)$ & $105(66.0)$ \\
\hline & \multicolumn{2}{|c|}{ Three and above } & $35(22.3)$ & $54(34.0)$ \\
\hline \multirow[t]{2}{*}{ Windows daily opening ( $n=326 ; 157$ for cases and 159 for control) } & \multicolumn{2}{|l|}{ Yes } & $35(22.3)$ & $141(88.7)$ \\
\hline & \multicolumn{2}{|l|}{ No } & $122(77.7)$ & $18(11.3)$ \\
\hline \multirow[t]{2}{*}{ Household is near the street } & \multicolumn{2}{|l|}{ Yes } & $53(32.3)$ & $15(9.1)$ \\
\hline & \multicolumn{2}{|l|}{ No } & $111(67.7)$ & $149(90.9)$ \\
\hline \multirow[t]{8}{*}{ Fuel material mostly used for cooking } & \multirow[t]{2}{*}{ Electric } & Yes & $39(23.8)$ & $69(42.1)$ \\
\hline & & No & $125(76.2)$ & $95(57.9)$ \\
\hline & \multirow[t]{2}{*}{ Charcoal } & Yes & $42(25.6)$ & $58(35.4)$ \\
\hline & & No & $122(74.4)$ & $106(64.6)$ \\
\hline & \multirow[t]{2}{*}{ Kerosene } & Yes & $4(2.4)$ & $5(3.0)$ \\
\hline & & No & $160(97.6)$ & $159(97.0)$ \\
\hline & \multirow[t]{2}{*}{ Wood } & Yes & $110(67.1)$ & $71(48.2)$ \\
\hline & & No & $54(32.9)$ & $76(46.3)$ \\
\hline \multirow[t]{3}{*}{ Mainly used cooking room } & \multicolumn{2}{|c|}{ In the living room } & $10(6.7)$ & $10(6.1)$ \\
\hline & \multicolumn{2}{|c|}{ Kitchen attached to living room } & $52(42.1)$ & $16(9.8)$ \\
\hline & \multicolumn{2}{|c|}{ In the separate kitchen } & $102(51.2)$ & $138(84.1)$ \\
\hline \multirow[t]{2}{*}{ Child stays during cooking } & \multicolumn{2}{|c|}{ Hold on my back } & $57(34.8)$ & $30(18.3$ \\
\hline & \multicolumn{2}{|c|}{ Out cooking room } & $107(65.2)$ & $134(81.7)$ \\
\hline \multirow[t]{2}{*}{ Who give care for child most of the time? } & \multicolumn{2}{|l|}{ Parents } & $119(72.6)$ & $141(86.0)$ \\
\hline & \multicolumn{2}{|c|}{ House worker and relatives } & $45(27.6)$ & $23(14.0)$ \\
\hline Cigarette smoking family member & Yes & & $6(3.7)$ & $1(0.6)$ \\
\hline & No & & $158(96.3)$ & $163(99.4)$ \\
\hline If yes, who smokes? & Father & & $6(100)$ & $0(0)$ \\
\hline & Other fam & & $0(0)$ & $1(100)$ \\
\hline Hand washing practice before child feeding & Only wate & & $82(50.0)$ & $31(18.9)$ \\
\hline & Water anc & & $3(1.8)$ & $10(6.1)$ \\
\hline & Water anc & & $79(48.2)$ & $123(75.0)$ \\
\hline Do you have domestic animals? & Yes & & $75(45.7)$ & $58(35.4)$ \\
\hline & No & & $89(54.3)$ & $106(64.6)$ \\
\hline Are animals kept in the same house? & Yes & & $33(44.0)$ & $13(22 . .4)$ \\
\hline & No & & $42(56.0)$ & $45(77.6)$ \\
\hline
\end{tabular}

facilities was likely a risk factor for childhood pneumonia among urban children [13]. This could be explained by the fact that in areas where street are grave and dusty, the probability of developing respiratory related diseases is high. Streets in small towns of Ethiopia (including Debre Markos referral hospital catchment area- the current study area) are usually dusty especially during winter season which might predispose children to pneumonia.
Regards to hand washing practice before feeding a child, those respondents who had used water only were at higher odds of developing pneumonia than those who had used water and soap. The World Health Organization recommends children and care takers should wash their hands at critical times throughout the day with water and soap to decrease the risk of exposure to bacteria and other microbial agents which can cause pneumonia [26]. 
Table 3 Different morbidities related to pneumonia among 2-59 months old children in Debre Markos Referral Hospital, Northwest Ethiopia, 2018 ( $n=164$ cases and 164 controls)

\begin{tabular}{|c|c|c|c|}
\hline \multirow[t]{2}{*}{ Factors } & \multirow[t]{2}{*}{ Category } & \multirow{2}{*}{$\begin{array}{l}\text { Case } \\
\text { N (\%) }\end{array}$} & \multirow{2}{*}{$\begin{array}{l}\text { Control } \\
\text { N (\%) }\end{array}$} \\
\hline & & & \\
\hline \multirow[t]{2}{*}{ Pneumonia in the family in the last 2 wks? } & Yes & $10(6.1)$ & $6(3.7)$ \\
\hline & No & $154(93.9)$ & $158(96.3)$ \\
\hline \multirow[t]{2}{*}{ Child treated pneumonia in 2 weeks } & Yes & $9(5.5)$ & $4(2.4)$ \\
\hline & No & $155(94.5)$ & $160(97.5)$ \\
\hline \multirow[t]{2}{*}{ Asthma for the child } & Yes & $8(4.9)$ & $4(2.4)$ \\
\hline & No & $156(95.1)$ & $160(97.6)$ \\
\hline \multirow[t]{2}{*}{ Upper respiratory tract infection in the past 2 weeks for the child } & Yes & $107(65.2)$ & $16(9.8)$ \\
\hline & No & $57(34.8)$ & $148(91.2)$ \\
\hline \multirow[t]{2}{*}{ Upper respiratory tract infection in the past 2 weeks in the family } & Yes & $114(69.5)$ & $12(7.3)$ \\
\hline & No & $50(30.5)$ & $152(92.7)$ \\
\hline \multirow[t]{2}{*}{ Malnutrition for the child } & Yes & $10(6.1)$ & $11(6.7)$ \\
\hline & No & $154(93.9)$ & $153(93.3)$ \\
\hline \multirow[t]{2}{*}{ Diarrhea for the child } & Yes & $37(22.6)$ & $18(11.0)$ \\
\hline & No & $127(77.4)$ & $146(89.0)$ \\
\hline \multirow[t]{2}{*}{ Family member Tb infection history } & Yes & $9(5.5)$ & $2(1.2)$ \\
\hline & No & $155(94.5)$ & $162(98)$. \\
\hline \multirow[t]{2}{*}{ Child Tb infection history } & Yes & $1(0.6)$ & $1(0.6)$ \\
\hline & No & $163(99.4)$ & $163(99.4)$ \\
\hline \multirow[t]{2}{*}{ First visit for sick baby } & Traditional healer & $14(8.5)$ & $3(1.8)$ \\
\hline & Health facility & $150(91.5)$ & $161(98.2)$ \\
\hline \multirow[t]{2}{*}{ HIV tested } & Yes & $152(92.7)$ & $73(44.5)$ \\
\hline & No & $12(.3)$ & $91(55.5)$ \\
\hline \multirow[t]{2}{*}{ If yes, test result } & Non-reactive & $149(98.0)$ & $71(97.5)$ \\
\hline & Reactive & $3(2.0)$ & $2(2.7)$ \\
\hline
\end{tabular}

Table 4 Nutritional related to pneumonia in Debre Markos Referral Hospital, Northwest Ethiopia, 2018 ( $n=164$ cases and 164 controls)

\begin{tabular}{|c|c|c|c|}
\hline \multirow[t]{2}{*}{ Variables } & \multirow[t]{2}{*}{ Category } & Case & Control \\
\hline & & N (\%) & N (\%) \\
\hline \multirow[t]{2}{*}{ Breast feeding practice (birth to 6 months) } & Exclusive breast feeding & $66(40.2)$ & $148(90.2)$ \\
\hline & Mixed & $98(59.8)$ & $16(9.8)$ \\
\hline \multirow[t]{2}{*}{ Weight for height (WFH) } & Wasted & $22(13.4)$ & $14(8.5)$ \\
\hline & Normal & $142(86.6)$ & $150(91.5)$ \\
\hline \multirow[t]{2}{*}{ Weight for age (WFA) } & Under weight & $21(12.8)$ & $13(7.9)$ \\
\hline & Normal & $143(87.8)$ & $151(92.1)$ \\
\hline \multirow[t]{2}{*}{ Vitamin A Supplementation } & Yes & $81(37.5)$ & $42(37.5)$ \\
\hline & No & $135(62.5)$ & $70(62.5)$ \\
\hline \multirow[t]{2}{*}{ Vaccination status appropriate for age } & Yes & $137(83.5)$ & $151(92.1)$ \\
\hline & No & $27(16.5)$ & $13(7.9)$ \\
\hline
\end{tabular}


Table 5 Determinants of pneumonia among 2-59 months old children in Debre Markos referral hospital, Northwest Ethiopia, 2018 ( $n=164$ cases and164 controls)

\begin{tabular}{|c|c|c|c|}
\hline Variables & Category & COR $(95 \% \mathrm{Cl})$ & AOR $(95 \% \mathrm{Cl})$ \\
\hline \multirow[t]{3}{*}{ Age of child (months) } & $2-11$ & $4.34(2.59,7.55)$ & $2.35(0.83,6.71)$ \\
\hline & $>11$ to $\leq 23$ & $2.64(1.51,4.63)$ & $1.76(0.66,4.71)$ \\
\hline & $>23$ to 59 & 1 & 1 \\
\hline \multirow[t]{5}{*}{ Mother's educational level } & Can't read and write & $3.71(1.37,10.02)$ & $7.16(0.77,66.75)$ \\
\hline & Primary & $2.48(0.88,6.98)$ & $4.99(0.66,37.55)$ \\
\hline & Secondary & $4.56(1.52,13.30)$ & $2.49(0.35,17.75)$ \\
\hline & Diploma & $1.80(0.61,5.31)$ & $4.65(0.68,31.80)$ \\
\hline & Degree and above & 1 & 1 \\
\hline \multirow[t]{2}{*}{ Family member } & $\leq 4$ & 1 & 1 \\
\hline & $\geq 5$ & $1.80(1.16,2.79)$ & $2.13(0.93,4.98)$ \\
\hline \multirow[t]{2}{*}{ Windows daily opening } & Yes & 1 & 1 \\
\hline & No & $27.31(14.70,50.70)$ & $6.15(2.55,14.83)$ \\
\hline \multirow[t]{3}{*}{ Mainly used cooking room } & In the living room & $1.35(0.54,3.30)$ & $0.97(0.19,5.11)$ \\
\hline & Attached to living room & $4.39(2.38,8.14)$ & $3.35(0.96,11.03)$ \\
\hline & Separate kitchen & 1 & 1 \\
\hline \multirow[t]{2}{*}{ Mostly child care giver } & Parents & 1 & 1 \\
\hline & House worker and relatives & $2.32(1.33,4.05)$ & $2.97(1.11,7.93)$ \\
\hline \multirow[t]{3}{*}{ Hand wash before child feeding } & Only water & $4.12(2.50,6.80)$ & $3.81(1.51,9.66)$ \\
\hline & Water and ash & $0.47(0.13,1.75)$ & $0.38(0.03,4.84)$ \\
\hline & Water and soap & 1 & 1 \\
\hline \multirow[t]{2}{*}{ Birth to 6 months breast feeding } & Exclusive breast feeding & 1 & 1 \\
\hline & Mixed & $13.50(5.30,25.10)$ & $7.62(2.97,19.55)$ \\
\hline \multirow[t]{2}{*}{ House near the street } & Yes & $4.74(2.54,8.85)$ & $4.23(1.56,11.44)$ \\
\hline & No & 1 & 1 \\
\hline \multirow[t]{2}{*}{ Vaccination appropriate for age } & Yes & 1 & 1 \\
\hline & No & $0.44(0.21,0.88)$ & $0.50(0.08,3.04)$ \\
\hline \multirow[t]{2}{*}{ URTI in the last 2 weeks } & Yes & $17.36(9.45,31.80)$ & $5.33(2.16,13.19)$ \\
\hline & No & 1 & 1 \\
\hline \multirow[t]{2}{*}{ Co-residence with URTI person } & Yes & $28.8(14.7,56.73)$ & $6.20(2.36,16.15)$ \\
\hline & No & 1 & 1 \\
\hline
\end{tabular}

Note: variables were included in the adjusted model based on a $p$-value of $<0.25$ in the unadjusted model

In relation to breastfeeding practice in the first six months of life, the odds of developing pneumonia in children who were on mixed breastfeeding practice was higher as compared to children who were exclusively breastfed during their birth to six months old duration. This is consistent with previous studies $[16,17,27,28]$. This could be due to the fact that children who were not exclusively breastfed were more prone to infections like pneumonia as a result of sub optimal feeding practice. WHO recommends that the infant should only receive breast milk without any additional food or drink, not even water since breast milk is the ideal food for the healthy growth and development of infant [29].
This study also revealed that children who had URTI in the last 2 weeks were more likely to develop pneumonia than those who did not have URTI. It is consistent with a study conducted in Southwest Ethiopia [16] which reported that children with previous upper respiratory tract infection were 5.2 times more likely to develop pneumonia as compared to their counterparts. Additionally, this study found that having history of coresidence with a family member who had URTI was strongly associated with developing pneumonia which is in line with other recent studies $[14,19]$. The possible explanation might be due to the fact that URTIs are highly communicable and can be transferred through air born, direct, and indirect contacts. Then, once the 
infection established, it permits invasion of the lung by microorganisms that trigger the immune response and produce inflammation [30,31].

\section{Conclusions}

In the present study, factors related with pneumonia were windows daily opening status, household near to street, child care giver most of the time, hand washing material used before child feeding, birth to 6 months breast feeding practice, URTI in the last 2 weeks for the child and a child with history of co- residency with family member who had URTI. These determinants are preventable with no or minimal cost. Therefore, we recommend appropriate and adequate health education regarding pneumonia prevention and control.

\section{Abbreviations}

(EFMOH): Federal Ministry of Health of Ethiopia; AIDS: Acquired Immune Deficiency Syndrome; AOR: Adjusted Odd Ratio; COR: Crude Odd Ratio; GAPPD: Global Action Plan for Pneumonia and Diarrhea; HIV: Human Immune Deficiency Virus; OPD: Out-Patient Department; OR: Odd ratio; SPSS: Statistical Package for Social Sciences; UNICEF: United Nations Children's Fund; URTI: Upper Respiratory Tract Infection; WHO: World Health Organization

\section{Acknowledgements}

Authors would like to thank Debre Markos referral hospital, supervisor, data collectors, and study participants.

\section{Authors' contributions}

SG: conceived, designed the study, supervised the data collection, and performed the data analysis, interpretation of the result, and drafting the manuscript. GA, MM, YM, TT, GM, and YAB participated in designing the study, data analysis, and data interpretation. YM and YAB drafted the manuscript. All authors read and approved the final manuscript.

\section{Funding}

Not applicable.

\section{Availability of data and materials}

The data of this study cannot be shared publically due to the presence of sensitive (confidential) participants' information.

\section{Ethics approval and consent to participate}

Ethical clearance was obtained from Ethical Review Committee (ERC) of Debre Markos University, College of Health Sciences. Permission to conduct the study was also obtained from Debre Markos Referral Hospital administrators before data collection. Written consent was obtained from mothers after they were informed about the study objectives, expected outcomes, benefits and the risks associated with it. Confidentiality and privacy of every respondent's information were ensured.

\section{Consent for publication}

Not applicable.

\section{Competing interests}

Authors declared that they have no conflict of interest.

\section{Author details}

'Debre Markos Referral Hospital, Debre Markos, Ethiopia. ${ }^{2}$ Collegeof Health Sciences, Debre Markos University, Debre Markos, Ethiopia. ${ }^{3}$ Collegeof Medicine and Health Science, Bahir Dar University, Bahir Dar, Ethiopia. ${ }^{4}$ Ethiopian Public Health Institute, Addis Ababa, Ethiopia.
Received: 28 March 2019 Accepted: 29 July 2019

Published online: 13 August 2019

\section{Referrences}

1. UNICEF. Child Mortality. https://data.unicef.org/topic/child-survival/underfive-mortality/ in 2018. 2018.

2. Izadnegahdar R, Cohen AL, Klugman KP, Qazi SA. Childhood pneumonia in developing countries. The Lancet Respiratory Medicine. 2013;1(7):574-84.

3. Organization $\mathrm{WH}$, Unicef: Ending preventable child deaths from pneumonia and Diarrhoea by 2025: the integrated global action plan for pneumonia and Diarrhoea (GAPPD). 2013.

4. FMoHo E. Introducing Pneumococcal Conjucate Vaccine in Ethiopia. Training Manual for Health Workers; 2011.

5. Le P, Griffiths UK, Anh DD, Franzini L, Chan W, Pham H, Swint JM. The economic burden of pneumonia and meningitis among children less than five years old in Hanoi, Vietnam. Trop Med Int Health. 2014;19(11):1321-7.

6. Li Y, An Z, Yin D, Liu Y, Huang Z, Ma Y, Li H, Li Q, Wang H. Disease burden of community acquired pneumonia among children under 5 y old in China: A population based survey. Human Vaccines Immunotherapeutics. 2017:13(7):1681-7.

7. Sirisuksan $\mathrm{V}$, Trung $\mathrm{Q}$, Riewpaiboon A: Cost of pneumonia in children: $\mathrm{A}$ systematic review.

8. Tan KK, Dang DA, Kim KH, Kartasasmita C, Kim HM, Zhang X-H, Shafi F, Yu T-W, Ledesma E, Meyer N. Burden of hospitalized childhood communityacquired pneumonia: A retrospective cross-sectional study in Vietnam Malaysia, Indonesia and the Republic of Korea. Human Vaccines Immunotherapeutics. 2018;14(1):95-105

9. Usuf E, Mackenzie G, Sambou S, Atherly D, Suraratdecha C. The economic burden of childhood pneumococcal diseases in The Gambia. Cost Effectiveness Resource Allocation. 2016;14(1):4

10. Memirie ST, Metaferia ZS, Norheim OF, Levin CE, Verguet $S$, Johansson KA. Household expenditures on pneumonia and diarrhoea treatment in Ethiopia: a facility-based study. BMJ global health. 2017;2(1):e000166.

11. Verguet S, Memirie ST, Norheim OF. Assessing the burden of medical impoverishment by cause: a systematic breakdown by disease in Ethiopia. BMC medicine. 2016;14(1):164.

12. Abuka T. Prevalence of pneumonia and factors associated among children 2-59 months old in Wondo Genet district, Sidama zone, SNNPR, Ethiopia. Current Pediatric Research. 2017:21:1.

13. Chang J, Liu W, Huang C. Residential Ambient Traffic in Relation to Childhood Pneumonia among Urban Children in Shandong, China: A CrossSectional Study. International journal of environmental research and public health. 2018;15(6):1076.

14. Dadi AF, Kebede $Y$, Birhanu Z. Determinants of pneumonia in children aged two months to five years in urban areas of Oromia Zone, Amhara Region, Ethiopia. Open Access Library Journal. 2014;1(08):1.

15. Fekadu GA, Terefe MW, Alemie GA. Prevalence of pneumonia among under-five children in Este Town and the surrounding rural Kebeles, Northwest Ethiopia: a community based cross sectional study. Sci J Public Health. 2014:2(3):150-5.

16. Geleta D, Tessema F, Ewnetu H. Determinants of Community Acquired Pneumonia among Children in Kersa District, Southwest Ethiopia: Facility Based Case Control Study. J Pediatr Neonatal Care. 2016;5(2):00179.

17. Nguyen T, Tran T, Roberts C, Fox G, Graham S, Marais B. Risk factors for child pneumonia-focus on the Western Pacific Region. Paediatric Respiratory Rev. 2017:21:95-101.

18. Nirmolia N, Mahanta TG, Boruah M, Rasaily R, Kotoky RP, Bora R. Prevalence and risk factors of pneumonia in under five children living in slums of Dibrugarh town. Clin Epidemiol Global Health. 2018;6(1):1-4.

19. Onyango D, Kikuvi G, Amukoye E, Omolo J. Risk factors of severe pneumonia among children aged 2-59 months in western Kenya: a case control study. Pan African Med J. 2012;13:1.

20. Amsalu ET, Akalu TY, Gelaye KA. Spatial distribution and determinants of acute respiratory infection among under-five children in Ethiopia: Ethiopian Demographic Health Survey 2016. PloS one. 2019;14(4):e0215572.

21. Hospital. DMR: Health Management Information System Report. 2018.

22. Health. FDRoEMo: Integrated Management of Newborn and Childhood Illness, Part 1; Blended Learning Module for the Health Extension Programme. http://www.open.edu/openlearncreate/pluginfile.php/71990/ mod_resource/content/2/IMNCI_Part.... 
23. Kelsey WE, Kelsey JL, Whittemore AS, Evans AS, Thompson WD. Methods in observational epidemiology, vol. 26: Monographs in Epidemiology and; 1996.

24. Iwan MRNAP, Ade RF. Risk Factor of Pnemonia among Children Aged Under 5 Years. A Case Control Study in Samarinda, Indonesia. Int J Med Sci Clin Invention. 2018:5(3).

25. Yin R, Dai T, Avci P, Jorge AES, de Melo WC, Vecchio D, Huang Y-Y, Gupta A, Hamblin MR. Light based anti-infectives: ultraviolet C irradiation, photodynamic therapy, blue light, and beyond. Current Opinion Pharmacol. 2013;13(5):731-62.

26. Safety WP. Organization WH: WHO guidelines on hand hygiene in health care; 2009

27. Chung M, Raman G, Chew P, Magula N, Trikalinos T, Lau J. Breastfeeding and maternal and infant health outcomes in developed countries. Evid Technol Asses (Full Rep). 2007;153(153):1-186

28. Lamberti LM, Zakarija-Grković I, Walker CLF, Theodoratou E, Nair H, Campbell H, Black RE. Breastfeeding for reducing the risk of pneumonia morbidity and mortality in children under two: a systematic literature review and meta-analysis. BMC public health. 2013;13(3):S18.

29. développement OmdlsDse, Staff WHO, Organization WH, UNICEF. Global strategy for infant and young child feeding: World Health Organization; 2003.

30. Mani CS, Murray DL. Acute pneumonia and its complications. In: Principles and Practice of Pediatric Infectious Diseases: Fourth Edition. edn.: Elsevier Inc. p. 2012.

31. Margolis P, Gadomski A. Does this infant have pneumonia? Jama. 1998;279(4):308-13.

\section{Publisher's Note}

Springer Nature remains neutral with regard to jurisdictional claims in published maps and institutional affiliations.

Ready to submit your research? Choose BMC and benefit from:

- fast, convenient online submission

- thorough peer review by experienced researchers in your field

- rapid publication on acceptance

- support for research data, including large and complex data types

- gold Open Access which fosters wider collaboration and increased citations

- maximum visibility for your research: over $100 \mathrm{M}$ website views per year

At BMC, research is always in progress.

Learn more biomedcentral.com/submissions 